\title{
Ko te Tika, ko te Pono, ko te Aroha: Exploring Māori values in the university
}

\section{Abstract}

This research is offered as a koha (contribution) to the ongoing debates within the university where all coauthors work as academic staff, Auckland University of Technology (AUT) in Auckland, Aotearoa New Zealand. We set out to critically investigate three key Māori words, tika, pono, aroha, and the results of their adoption as 'university values' by AUT. In the sections below, we synopsise and synthesise scholarly literature from a critical Māori perspective, informed by collective lived experience, including our experiences of being Māori academics, working at AUT. This research offers an internal critique of our employer university and is therefore an exercise in academic freedom and a form of

Georgina Tuari Stewart (Ngāti Kura, Ngāpuhi-nui-tonu, Ngāti Maru ki Tainui) is an Associate Professor in Te Kura Mātauranga-School of Education at AUT University

Valance Smith (Ngāti Mahuta, Ngāpuhi-nui-tonu, Ngāti Maru ki Tainui) is the Assistant Pro-Vice Chancellor Māori Advancement at AUT University

Piki Diamond (Ngāti Tūwharetoa, Ngāpuhi, Ngāti Pākehā, and raised by Tauranga Moana) is an academic developer within altLAB at AUT University

Nova Paul (Ngāpuhi) is a Senior Lecturer and artist in the School of Art and Design at AUT University

Robert Hogg (Ngāti Awa, Ngāi Tūhoe) is the Associate Dean, Māori Advancement (Undergraduate) for the Faculty of Health and Environmental Sciences at AUT University 
activist research, as is consistent with the political nature of Kaupapa Māori approaches. While this article restricts itself to one university, the conundrum of using Māori knowledge in educational and other contemporary social institutions is topical across the nation. The key question we investigate is: Are these three words, tika, pono, aroha, being used by AUT in ways consistent with their Māori meanings?

\section{Introduction}

This article explores the range of possible meanings of three Māori concepts-tika, pono, aroha-and considers the implications of their adoption as contemporary 'university values' in Aotearoa New Zealand. Five or so years ago, AUT formally adopted these three Māori terms as its values, which, according to its website, are 'at the heart of everything we do' (Auckland University of Technology, 2021, p. 6). Since then, these three AUT Values have featured in various staff workshops and internal policy and other documents. But are these three words being used by AUT in ways that are consistent with their traditional Māori meanings? What actually is being included in the university's thinking and practice, having taken this bold policy step? The knowledge questions involved in adopting ancient Indigenous concepts as university values deserve to be recognised and addressed. This article seeks constructively to contribute to this ongoing debate.

We draw on Māori-centred close readings of key scholarly sources to consider the questions raised by Māori university values, and these three AUT values in particular. Authored by Māori AUT academics, this internal critique relates to the particular circumstances 
encountered within this one university, but the discussion is topical for all tertiary institutions, schools, and other social domains. Details differ in each situation, but the underlying questions and debates are much the same. In its methodology this work aims to be 'activist scholarship' aligned with the traditions of 'academic freedom' (Moodie, 1996) as well as the principles of Kaupapa Māori theory, in the following ways: the viewpoints expressed are from a Māori person's perspective; the research aims centre on the interests of Māori people, language, knowledge and culture; and the wider role of research, including this article, is seen rightly as supporting Māori political aspirations (G. H. Smith, 2003; L. T. Smith, 2012).

There is an apparent disparity between the Māori and AUT interpretations and understandings of these three key words, aroha, tika and pono. To assimilate Indigenous concepts to Eurocentric meanings is a clear example of symbolic violence, which comes under the heading of neo-colonialism (Jackson, 1992). To appropriate Māori values into Pākehā meanings and frameworks tramples the philosophical rights of Māori people (Stewart, 2020). This problematic approach to policy constitutes an act of epistemic violence against Māori knowledge. It is therefore acting as a malignant policy in the sense that it damages Māori culture, language and people.

\section{What are university values?}

First, it is necessary to define 'university values' as the term will be used below. A vast literature exists on the study of institutional organisations, but in simple terms, an institutional 'value' in this context is a basic principle 
that is recognised as valuable for achieving the central mission of the institution (Cameron \& Quinn, 2011; Guala, 2016; Stinchcombe, 1997; Suddaby et al., 2010). Traditionally, the values of universities went unstated, accepted as being concerned primarily to uphold the unfettered pursuit of truth (Gaita, 2000). The explicit notion of 'university values' has emerged during recent decades of debate about the identities and roles of universities in society, catalysed by changing socioeconomic and sociopolitical circumstances. These debates about universities increased as market policies were adopted from the late 1980s onwards under the influence of neoliberalism, resulting in 'academic capitalism', which refers to the value of academic work being seen in terms of revenue generation through external research funding or commercialisation (Croucher \& Lacy, 2020; Loi \& Di Guardo, 2015; Slaughter \& Rhoades, 2004; Winter \& O'Donohue, 2012). An intriguing recent dispute over university values centred on the book Why Universities Matter: A conversation about values, means and directions (Coady, 2000). Based in Melbourne Australia, this book is a collection of essays based on scholarly conferences, held by the Centre for Philosophy and Public Issues of the University of Melbourne to discuss the changing nature of Australian universities in the wake of the broadly neoliberal Dawkins reforms (from 1988 onwards). A scandal arose when the first publisher, Melbourne University Press, reversed their initial support and declined to publish it, in a move widely viewed as thinlyveiled censorship of the university's own leading academics. The book was promptly published elsewhere, and (ironically) sold much better as a result of the 
controversy than it might have otherwise (Fraser, 2000). The Melbourne authors critiqued the values they saw operating in their own university, which were changing in ways that risked damaging the enduring mission or 'idea' of the university in being 'devoted to the pursuit of significant truth' (Coady, 2000, p. 6).

The Melbourne story chimes with this research in its intent to provide an internal critique of the values of our own university. In this case our purpose is to interrogate the AUT Values against their traditional Māori meanings. The Melbourne authors felt the need to protest against those aspects of recent 'management' reforms in their workplace that, in their view, damaged the received values of the university in relation to truth and seeking after truth, with such intellectual virtues as honesty, intellectual courtesy, indifference to mere fashion in ideas, and a dedication to the regulative ideal of truth' (Coady, 2000, p. 7). To thus delineate these essential values specific to the mission of the 'university' (distinct from any other social institution) makes a useful baseline for the discussions in the following sections, below.

A more optimistic view of the contemporary trend towards explicit definition by a university of its values is the Magna Charta Universitatum document (www.magnacharta.org). The Magna Charta initative began in 1988, timed to celebrate the 900th anniversary of the University of Bologna, Italy, acclaimed as the oldest existing university. The Magna Charta Living Values project encourages universities to define, engage with, and live in accordance with their values (Magna Charta, 2021):

To create and maintain public trust in universities amid today's complexity and uncertainty, universities need to define their values explicitly, clearly communicate them 
to staff, students, and stakeholders, and demonstrate that their values inform practice and decision-making. (Magna Charta, 2021)

On its inception, the Magna Charta constituent members (representing 388 universities across Europe, and beyond) agreed on the fundamental university values of 'academic freedom, institutional autonomy, and the concomitant responsibility to society' (Magna Charta, 2021). Later, other university values that could be developed locally were listed:

- integrity and fairness;

- equity;

- creativity, innovativeness, and excellence;

- social responsibility and community service;

- diversity, pluralism, and inclusiveness, and

- health, well-being, and a caring community. (Magna Charta, 2021)

In terms relevant to a self-critique of the AUT Values, the Living Values Project explains:

In selecting values institutions are advised to be quite clear about the conceptual and practical differences between high-level (as distinct from operational) values and how they may manifest in mission, politics, behaviours, processes, and structures. Adopting a small number of values is recommended; fewer values tend to be more memorable and thus more effective. (Magna Charta, 2021)

The relevance to universities of clearly defined values increases as the value and relevance of universities to society comes increasingly into question. The Magna Charta project posits explicit university values as part of 
a strategy-in effect, a corporate marketing strategy-for defending and re-thinking the identity and role of the university in a contemporary, globalised social milieu. These perspectives on university values provide a basis for considering the AUT values, and how they incorporate the three Māori concepts.

\section{The AUT Values}

The following explanation is taken from the AUT website:

Our values - tika, pono and aroha (integrity, respect and compassion) - are at the heart of everything we do.

Our integrity helps us do good work. We're genuine, accountable and efficient, and people know they can trust us to stay true to our word.

How we respond to each other makes a huge difference. That's why we're welcoming, helpful and kind, and always try to show each other compassion.

Respect is at the core of how we work together. We're collaborative, inclusive and open, and our staff value different viewpoints and challenge conventional ways of doing things; the same characteristics AUT graduates are well-known for.

This text is accompanied by the colourful AUT Values graphic as widely used in internal and branding documentation, which consists of four circles, side-byside from left to right, and superimposed with the texts shown below:

(Blue circle) TIKA - INTEGRITY Doing good work (our values)

(Purple circle) PONO - RESPECT How we work together (our values)

(Orange circle) AROHA - COMPASSION How we respond to one another (our values)

(Green circle) SUPPORTING ACHIEVEMENT.

(see Auckland University of Technology, 2021) 
For a university to adopt Māori values in its central policies is undoubtedly seen as an enlightened, innovative step, intended to demonstrate the commitment of the university to biculturalism, Te Tiriti o Waitangi, and principles of diversity and inclusiveness. The approach of adopting Māori values is in line with current trends towards increasing visibility of elements of Māori cultural knowledge in national life, including the adoption of Māori names and greetings in media, government agencies, and education. Bilingual signage and using Māori greetings on emails have become commonplace, even for organisations and individuals with no other apparent links to Māori language and culture. To adopt these three Māori concepts as its university values could be cited as evidence of AUT's cultural competence and embrace of te reo and tikanga Māori. From the perspective of Māori-speaking staff, however, there are problems with AUT's use of tika, pono and aroha, as outlined below. These points articulate Māori concerns about AUT's use of these key concepts in a provisional, representative way, making no claim to be authoritative or comprehensive.

The first problem we see is that the university policy treats tika, pono and aroha as three separate terms, distinct from each other. Second, the policy implies that each of these three terms can be equated to single English words, and aligned with statements written in standard policy language. Third, the single English words chosen to translate these three terms are problematic: the English headwords for 'tika' (integrity) and 'pono' (respect) seem to have been transposed, since pono (i.e. truth) is closer in meaning to integrity, and tika (i.e. ethical) is closer in meaning to respect. To translate 
'aroha' as compassion, while not incorrect, affords only a partial sense of its full meaning. Fourthly, these three Māori words seem orphaned, unintegrated into the institutional discourse. The webpage cited above is the only place they appear on the main AUT website, in the section about working at AUT, and they are the only three Māori words on that page. Their lack of integration into university life is highlighted by the ambivalent presence of a fourth circle, labelled Supporting Achievement, which is part of the 'Our Values' graphic, but is missing the label 'Our Values' that appears in small font on the other three circles. As already noted, these points of concern are not diagnostic but indicate something of the unease felt by Māori members of the AUT community about how these concepts are currently treated by AUT, and will be returned to at the end of the following section.

The difficulties with adopting these Māori words as university values are indicated by looking up their meanings. The online language database Wakareo (www.reotupu.co.nz) returns many English meanings for each of these three words. Meanings for tika include: straight, accurate, fair, apt, correct, decent, etc. Meanings for pono include: true, hospitable, dependable, devoted, earnest, religious, etc. Meanings for aroha include: love, yearning, pity, affection, mercy, condolence, etc. This simple dictionary exercise demonstrates the lack of correspondence between these three Māori words and the three English words used to translate them in the AUT Values. The next section explores Māori meanings of these three concepts in more detail.

\section{Māori understandings of tika, pono and aroha}


These three Māori words, tika, pono and aroha, are ancient Indigenous ethical value concepts (Patterson, 1992; Tate, 2012) that name integral aspects of Māori ontology. All such central Māori concepts are inextricably connected to each other (Salmond, 1982), conceptually and in application to practice, as cornerstones of the 'Māori worldview' that can also be regarded as 'te ao Māori'. To appreciate the full range of Māori meanings of tika, pono and aroha therefore depends on understanding Māori philosophy and its holistic frameworks of ontology, epistemology and ethics, within which these three concepts are derived and make sense (Stewart, 2020).

In post-contact Māori society, the adoption of these three words for use as 'institutional values' dates back over 150 years (see next paragraph). Today, these three terms are widely known as a framework for Māori cultural ethics; as a Māori, one encounters them at every turn, in all manner of formal and informal Māori discourse, from Facebook posts to whaikōrero (formal speeches and oratory). Their general applicability within Māori life, past and present, is illustrated by the following examples.

As presented in this article's title, i.e. 'ko te tika, ko te pono, ko te aroha' these three words form the masthead motto of a Māori-language newspaper (niupepa), Te Waka Māori o Ahuriri, which was published between 1863-1871 (Te Ara - The Encyclopedia of New Zealand, 2021). This niupepa was one of the first and most successful of about 50 niupepa titles, a genre that enjoyed enormous popularity in the colonial era, once printing presses arrived in the country (Curnow et al., 2002). In the niupepa, the three keywords are translated as justice, truth and love'-strong, fundamental concepts, deeper 
and broader than 'integrity, respect and compassion' as rendered in the AUT Values. That these three words were chosen as 'values' for this niupepa reflects the thenrevolutionary nature of a Māori medium newspaper, as one output of the notable early Māori enthusiasm for Māori-language literacy, and its resulting impact on Māori social discourse (Curnow et al., 2002; Jones \& Jenkins, 2011).

These three keywords also feature in a famous waiata (song), Mā Wai Rā, composed in 1933 by Henare Te Owai, from Ngāti Porou, as a lament on hearing of the death of his friend, Pine Tamahori (https://tewhanaulab.com/). The words of this waiata identify tika, pono and aroha as essential for the survival of the marae (Tate, 2012), which can be interpreted as a metaphor for Māori society. Today, this waiata Mā Wai Rā is widely taught in Māori language classes and sung on Māori occasions of all kinds. It is an iconic anthem of modern Māori culture; its words are taken as guidance for right action and leadership.

These three words were the focus of an MA thesis by Robin Peters (2000), who investigated their use in three novels by the famous Māori author, Patricia Grace. Peters notes that, although each word can stand alone,

... when considered together they encompass a concept which in translation means doing the right thing with integrity and love. This term, which is an aspect of whanaungatanga, may be described as central to a Māori sense of self and community' (Peters, 2000, p. 1, emphasis in original).

Having unpacked these three keywords into simple, accessible language, Peters continues: 
It is clear that the three work together and are facets of the same process. There are times when, for example, aroha may appear to be the motivating factor, but upon examination it is not unusual to discover that the act of aroha has been motivated by a person's belief that this is the tika thing to do, and pono, or integrity has given the power to put aroha into action. (Peters, 2000, p. 6)

Here Peters describes pono as the mediating principle between tika, knowing what is right, and aroha, taking right action. A similar interpretation is found on the website of an Auckland-based Māori health provider, Te Puna Hauora o te Raki Paewhenua (www.tepuna.org.nz). Under the heading 'Our Whakataukī (Proverbs)' appears the following text:

He aha te huarahi? - i runga i te TIKA, te PONO, me te AROHA.

What is the pathway? - it is doing what is right with integrity and compassion. (www.tepuna.org.nz/ourkaupapa)

Several extended analyses of Māori concepts and values have been written by esteemed Māori elder-scholars (Barlow, 1991; Mead, 2016, p. 8; Royal, 2003; Tate, 2012), including discussions of these three concepts, although each author has their own aims and particular slant. In his succinct explanations of 70 Māori cultural concepts, Cleve Barlow (1991) includes a listing for 'aroha (love, sympathy, charity)' (p. 8) but not tika or pono. Barlow describes aroha as a 'sacred power' and 'creative force that emanates from the gods' (Barlow, 1991, p. 8). 'Aroha in a person is an all-encompassing quality of goodness, expressed by love for people, land, birds and animals, fish, and all living things' (Barlow, 1991, p. 8). 
These depictions of aroha convey a strikingly different meaning from the single word 'compassion' used in the AUT Values.

Furthermore, Māori Marsden explains aroha as encapsulating the 'prime social values' of Māori society, including the attributes of 'loyalty, generosity, caring, sharing, [and] fulfilling one's obligations to the group' (Royal, 2003, pp. 41-42). Although tika and pono are not headwords in Barlow (1991), nor indexed items in Marsden (Royal, 2003), they are implicit throughout both books.

Conversely, in his account of tikanga Māori, Hirini Moko Mead (2016) posits tika and pono as fundamental principles and values. 'The concept of tika, or being correct, is a base principle that applies to all tikanga' ( $\mathrm{p}$. 29). Mead advises that pono is equally important in making judgements about correctness. The concept of pono means true or genuine, 'that is, true in terms of the principles of Māoritanga' (p. 29). Aroha, Mead notes, 'is an essential part of manaakitanga and [an] expected dimension of whanaungatanga' (p. 32). Mead's glossary lists these three words as follows:

aroha - love, respect, compassion (p. 391)

pono - true to the principles of culture (p. 397)

tika - appropriate behaviour, good grace (p. 400)

(Mead, 2016)

Finally there is the authoritative work of Pā Henare Arekatera Tate $(2010,2012)$ whose doctoral thesis developed a Māori form of Christian theology from first principles of Indigenous Māori cultural concepts and values. Tate names tapu as the fundamental principle, without which nothing else would exist. Mana is the 
second foundational concept, closely related to tapu, and both are seen as underlying all the other concepts. Next come the principles of pono, tika and aroha, which are dealt with together, as principles directing the proper exercise of mana. 'Each of them addresses, manifests, enhances, sustains and restores tapu and mana' (Tate, 2010, p. 114). In describing the entanglements between these basic principles, Tate's description is echoed by Mead's: 'Tapu is inseparable from mana, from our identity as Māori and from our cultural practices' (Mead, 2016, p. 33).

The fourth chapter of Tate's thesis, titled PONO (Truth, Integrity), TIKA (Right Order and Right Response), AROHA (Love, Affection, Compassion) is particularly useful. Tate varies the received order in treating pono first, on the grounds that pono concerns knowledge of reality, which precedes and is presupposed by tika (right response to reality) and aroha (loving response to reality). Tate defines pono as:

- A principle of truth by which we address tapu and mana;

- An ethical principle of action that qualifies how we address tapu and exercise mana;

- The basis of tika and aroha. (Tate, 2010, p. 116).

Next, Tate considers the range of meanings of tika, which include straight, direct, just, fair, right and correct. Tika also means justice, and authority, in which case it is synonymous with mana (Tate, 2010, p. 125). Tika consists in right acknowledgement of tapu and mana, right ordering of relationships among atua, tangata and whenua, and appropriate response to tapu by the right 
exercise of mana. Tika presupposes pono, and is the basis for aroha (Tate, 2010, p. 126).

Finally, Tate examines aroha, which according to authoritative sources includes the meanings of love, yearning for an absent friend, pity, compassion, affectionate regard, mercy, sorrow, generosity and sacrifice (p. 133). Aroha is 'the essential element in interpersonal relationships' and Tate notes 'there is no single English word that covers all the perspectives of aroha' (p. 134).

In terms of the relationship between these three concepts, aroha is based on pono and tika. Pono can be exercised with tika, and tika must be exercised with pono, but both can be superseded by aroha. Tate seems to be saying that aroha is the essence of being human and essential to the fullness of our encounter with reality. Together with the notions of 'all-encompassing goodness' and 'supreme, creative power' these accounts clarify the full range of meaning of aroha.

This exploration of the Māori meanings of these three words supports the concerns raised above about their use as AUT Values, in response to which, the following preliminary insights can be discerned:

1. Tika, pono and aroha are not separate nor separable concepts, but are closely intertwined aspects of traditional Māori understandings of the nature of reality, of the human, and of right action in the world, underpinned by other key Māori concepts such as mana and tapu.

2. Pono is closest in meaning to truth, with which a university is centrally concerned. Tika is a central principle of ethical behaviour towards other people 
and the world. Aroha is a supreme power and the essence of humanity. To equate pono with respect, tika with integrity, and aroha with compassion falls far short of the full Māori meanings.

3. These three concepts are ubiquitous and of high stature among Māori society, past, present and future, so to adopt them as institutional values implies a profound commitment and entails a profound responsibility on the part of AUT. They may be the 'AUT Values' but they are not and could never be 'AUT's values': they are value concepts derived from, and belonging to, te ao Māori me ōna tikanga (the Māori world and its philosophies).

Māori people, especially Māori speakers, are more likely than others to be aware of the disjunction between the AUT usages and the actual meanings of these three words, and hence to suffer the psycho-emotional discomfort caused by that awareness. The next section suggests a way forward from this impasse, based on appropriating another traditional Māori concept, rāhui (customary prohibition of use), for educational purposes.

\section{Māori knowledge as cognitive resource: Rāhui as Māori pedagogy}

Māori knowledge has been widely adopted into non-Māori contexts, which shows how Māori knowledge acts as a cognitive resource in the contemporary wider world, te ao whānui. It seems reasonable to invoke a Māori custom for resource management, rāhui, extrapolating its use into the intellectual realm of education, as a cognitive tool or 'intervention' by which to safeguard the integrity of our philosophical taonga (treasures) and resources, including 
these three words, pono, tika, aroha. This approach adopts rāhui as a Māori pedagogy, by which to engage in a cross-cultural educational relationship with/in our university community.

Non-traditional adaptations of the use of rāhui into the realm of ideas are not without precedent: Hirini Moko Mead (2016) opens his book with a story about how his 'interest in tikanga' began in 1979 when he suggested that a rāhui be placed on Māori playing rugby with South Africa, to protest against their apartheid policies by which the White ruling classes kept Black people trapped in grinding poverty. An uproar ensued: The very idea of applying a Māori concept to a highly political issue raised hackles around the country and caused some furious debate on marae and in the pubs of the land.' (Mead, 2016 , p. 1). Yet those very debates are what has made Aotearoa New Zealand the country it is today; the envy of the world in our ability to respond intelligently when global threats strike (e.g. the 2020 pandemic).

In the natural environment where the custom of rāhui is traditionally practiced, when the mauri (life force) or the hau (vitality) is reduced for whatever reason (e.g. overharvesting, severe weather events), rāhui in the form of temporary restrictions would be placed on these resources, until their condition improved or became rejuvenated. Rāhui is not about managing resources, but rather about managing people's behaviour in relation to the resource. Rāhui is a cultural framework that safeguards mana and tapu.

In terms of the AUT Values, therefore, a rāhui applies not to the words themselves, but to how people at AUT are thinking about and using those words in the relevant institutional discourses. Our research has indicated the 
importance to a university like AUT of defining its values; having chosen to adopt these three Māori concepts, it is imperative to take their full meanings into account. The rāhui acts as a signal of the learning needed, in and by AUT, in relation to these three key words. These ancient Indigenous value concepts have a power that cannot be disguised by being transposed into policy speak.

To invoke a rāhui over the AUT Values is to flag a Māori concern with AUT's performance in relation to these three key words. Rāhui is a cultural assessment that proceeds according to a set of standards inherent within te ao Māori, and the authentic meanings of these three words. Traditional environmental standards are being extrapolated into the 'discourse environment' of AUT, a term intended to encompass all formal and informal aspects of communication. Rāhui is a response to AUT's failure to meet the expected (Māori) standards. To invoke an educational rāhui over the AUT Values puts a stake in the ground to signal the need for AUT to engage with its own Māori academics in relation to better representing, in its documentation and practices, the cultural centrality and richness of these three key Māori words.

\section{Conclusion}

We could do worse than return to the received values of the university, as described by the Melbourne authors cited above (Coady, 2000), in relation to truth and seeking after truth, with 'honesty, intellectual courtesy, indifference to mere fashion in ideas, and a dedication to the regulative ideal of truth'. Honesty and truth most closely equate with pono. Intellectual courtesy and respect for scholarly rigour (our translation of 
'indifference to mere fashion in ideas') are part of tika. And dedication captures the essence of aroha. This research theorises the implications when Māori philosophical concepts are taken up by a university as its 'values' without serious attempts to engage with the full range of Māori meanings of the words concerned, such as has occurred, according to our investigations, with tika, pono, aroha at AUT. It is a conundrum of all work in the critical traditions, to which this work relates, to be constantly criticising the current state of affairs, but far less often rewarded with changes in the directions suggested. With that limitation in mind, we offer this article as a rhetorical pou rāhui, marking the need for educational cross-cultural conversations still to come. 


\section{Glossary of Māori words (as used in this article)}

\begin{tabular}{|c|c|}
\hline Aotearoa & Māori name for New Zealand \\
\hline aroha & love, compassion, goodness \\
\hline hau & vitality \\
\hline $\begin{array}{l}\text { he aha te } \\
\text { huarahi? }\end{array}$ & what is the pathway? \\
\hline i runga i te & along the lines of \\
\hline Kaupapa & Māori-centred theory and philosophy \\
\hline Iāori & \\
\hline ko te & (it is) \\
\hline koha & gift, contribution \\
\hline mana & $\begin{array}{l}\text { personal uniqueness, power and } \\
\text { prestige }\end{array}$ \\
\hline $\begin{array}{l}\text { manaakitanga } \\
\text { mānuka }\end{array}$ & $\begin{array}{l}\text { hospitality and taking care of others } \\
\text { native tree, here used in reference to } \\
\text { the wero }\end{array}$ \\
\hline Māori & $\begin{array}{l}\text { Indigenous peoples of Aotearoa New } \\
\text { Zealand }\end{array}$ \\
\hline Māoritanga & Māori culture and all things Māori \\
\hline mauri & life force \\
\hline me ōna & and its \\
\hline niupepa & newspaper \\
\hline pono & truth \\
\hline pou rāhui & marker post \\
\hline rāhui & cultural restriction \\
\hline take & the object laid down in a wero \\
\hline taonga & valuables, treasure \\
\hline tapu & set apart, restricted \\
\hline te ao Māori & the Māori world \\
\hline te ao whānui & the wider world \\
\hline te reo (Māori) & the Māori language \\
\hline
\end{tabular}


Te Tiriti o the Treaty of Waitangi

Waitangi

tika

justice, factually / ethically correct

tikanga

Māori customs

(Māori)

waiata

song, to sing

Wakareo

an online Māori language database

wero challenge ceremony

whaikōrero speechmaking, oratory

whakatauki proverbial saying

whanaungata relationships 


\section{References}

Auckland University of Technology. (2021). Our Values: Working

at AUT.

https://www.aut.ac.nz/about/careers-at-

aut/working-at-aut/what-its-like-to-work-ataut/our-values-working-at-aut

Barlow, C. (1991). Tikanga whakaaro: key concepts in Māori culture. Oxford University Press.

Cameron, K. S., \& Quinn, R. E. (2011). Diagnosing and Changing Organizational Culture: Based on the Competing Values Framework. John Wiley \& Sons.

Coady, T. (Ed.). (2000). Why Universities Matter: A conversation about values, means and directions. Allen $\&$ Unwin.

Croucher, G., \& Lacy, W. B. (2020, 2020/11/21). The emergence of academic capitalism and university neoliberalism: perspectives of Australian higher education leadership. Higher Education. https://doi.org/10.1007/s10734-020-00655-7

Curnow, J., Hopa, N., \& McRae, J. (Eds.). (2002). Rere atu, taku manu! Discovering history, language and politics in the Māori-language newspapers. Auckland University Press.

Fraser, M. (2000). The body in question. In T. Coady (Ed.), Why Universities Matter: A conversation about values, means and directions (pp. 235-249). Allen \& Unwin.

Gaita, R. (2000). Truth and the university. In T. Coady (Ed.), Why Universities Matter: A conversation about values, means and directions (pp. 26-48). Allen \& Unwin. 
Guala, F. (2016). Understanding Institutions : The Science and Philosophy of Living Together. Princeton University Press.

Jackson, M. (1992). The Treaty and the word: the colonization of Māori philosophy. In G. Oddie \& R. Perrett (Eds.), Justice, ethics and New Zealand society (pp. 1-10). Oxford University Press.

Jones, A., \& Jenkins, K. (2011). He Kōrero - Words between us: first Māori-Pakehā conversations on paper. Huia.

Loi, M., \& Di Guardo, M. C. (2015). The third mission of universities: An investigation of the espoused values. Science and Public Policy, 42, 855-870. https://doi.org/10.1093/scipol/scv012

Magna Charta. (2021). Living Values Project. http://www.magna-charta.org/activities-andprojects/living-values-project

Mead, H. M. (2016). Tikanga Māori: Living by Māori values (Rev. ed.). Huia Publishers. (2003)

Moodie, G. C. (1996). On Justifying the Different Claims to Academic Freedom. Minerva, 34(2), 129-150.

Patterson, J. (1992). Exploring Māori values. Dunmore Press.

Peters, R. J. (2000). Tika, Pono and Aroha in three novels by Patricia Grace [MA thesis] Massey University].

Royal, T. A. C. (Ed.). (2003). The Woven Universe: selected writings of Rev. Māori Marsden. The Estate of Rev. Māori Marsden.

Salmond, A. (1982). Theoretical Landscapes. In D. Parkin (Ed.), Semantic Anthropology (pp. 65-87). Academic Press. 
Slaughter, S., \& Rhoades, G. (2004). Academic capitalism and the new economy: Markets, state, and higher education. Johns Hopkins University Press. http://www.loc.gov/catdir/bios/jhu051/200302478 $\underline{\text { 3.html }}$

Stewart, G. T. (2020). Māori Philosophy: Indigenous thinking from Aotearoa. Bloomsbury.

Stinchcombe, A. L. (1997, 1997/08/01). On the Virtues of the Old Institutionalism. Annual Review of Sociology, 23(1), 1-18. https://doi.org/10.1146/annurev.soc.23.1.1

Suddaby, R., Elsbach, K. D., Greenwood, R., John W. Meyer, J. W., \& Zilber, T. B. (2010). Organizations and their Institutional Environments-Bringing Meaning, Values, and Culture back in: Introduction to the Special Research Forum. Academy of Management Journal, 53(6), 1234-1240.

Tate, H. A. (2010). Towards Some Foundations of a Systematic Māori Theology (PhD thesis). University of Melbourne.

Tate, P. H. (2012). He Puna Iti $i$ te Ao Marama: A Little Spring in the World of Light. Libro International.

Te Ara - The Encyclopedia of New Zealand. (2021). Te Waka Maori o Ahuriri. https://teara.govt.nz/en/zoomify/42402/te-wakamaori-o-ahuriri

Winter, R. P., \& O'Donohue, W. (2012, 2012/12/01). Academic identity tensions in the public university: which values really matter? Journal of Higher Education Policy and Management, 34(6), 565-573. https://doi.org/10.1080/1360080X.2012.716005 

university 